\title{
Epidemiological profile of elderly patients with non-melanoma skin cancer seen at the dermatology outpatient clinic of a public hospital*
}

\author{
Thiara Cristina Rocha Lenzi ${ }^{1}$ \\ Maria Rita Carvalho Garbi Novaes ${ }^{2}$
}

\author{
Carmelia Matos Santiago Reis ${ }^{2}$
}

DOI: http:/ / dx.doi.org/10.1590/abd1806-4841.20175701

\begin{abstract}
Basal cell carcinoma and Squamous cell carcinoma, referred to as non-melanoma skin cancer, are the most common malignancies in humans. Their incidence is increasing worldwide every year. In Brazil, even with the advent of educational campaigns on photoprotection and laws that banned tanning beds, they are the most frequent neoplasias, representing a public health problem recognized by the Ministry of health.
\end{abstract}

Keywords: Aged care; Carcinoma, basal cell; Carcinoma, squamous cell; Social conditions; Elderly; Neoplasms, basal cell; Neoplasms, squamous cell; Skin neoplasms; Health of the elderly

Basal cell carcinoma (BCC) and squamous cell carcinoma (SCC), commonly referred to as non-melanoma skin cancers (NMSC), are the most common neoplasias in humans. Their incidence has been increasing every year throughout the world. ${ }^{1}$ In Brazil, even with educational campaigns about photoprotection and laws that prohibited artificial tanning beds, they are the neoplasias with higher incidence, representing a public health concern recognized by the Ministry of Health. For the year of 2016, 175,760 new cases of NMSC are estimated in the population, approximately a third of all the neoplasias recorded in the country. ${ }^{2}$ NMSC have a good prognosis, with high cure rates if treated early and adequately. Despite low mortality, situations in which there is a delay in the diagnosis can lead to skin ulcerations and severe physical deformities, with high morbidity, becoming a burden for health institutions. ${ }^{2,3}$

NMSC incidence is increasing all over the world every year and can be increased even further by the population aging process. Eighty percent of NMSC diagnoses are made in people older than 55 years of age. Even if it affects young adults and kids, it is a condition essentially of the elderly. ${ }^{4}$

Brazilian population has been going through a significant aging process, leading to a transformation in the epidemiologic profile towards the predominance of chronic, non-transmissible diseases, with cancer being one of them. Therefore, it is crucial that the health services adapt to the needs of this part of the population, providing it good quality medical care.

For this reason, studies aiming at better understanding the health issues of the elderly with NMSC and the histological types of tumors that most often affect them will be able to offer us scientific data in order to guide the development of guidelines of care to the elderly individuals affected by this condition and help allocate resources in strategies of prevention and early diagnosis.

So, as to become more familiar with the epidemiological profile of the elderly with NMSC seen at a dermatology outpatient clinic at a tertiary public hospital in Brasília, we conducted an observational and analytic study. One hundred and one individuals of both sexes, aged 60 years or older were eligible for the study, selected among the elderly diagnosed with NMSC previously confirmed by histopathology, seen at the Advanced Surgery outpatient clinic at Hospital Regional da Asa Norte, Secretaria de Estado de Saúde do Distrito Federal, between 13/02/2015 and 31/10/2015. It is a referral and counter-referral clinic, with availability to receive skin cancer patients referred from other dermatology services of the hospital system in Distrito Federal. A protocol for data collection was created and approved by the Ethics in Research Committee (108272/2015). For the statistical analysis, we used software R, version 3.2.1, and Excel (part of Microsoft Office Professional Plus 2010), version 14.0.6023.1000. Results are shown in Table 1.

Received on 15.02.2016.

Approved by the Advisory Board and accepted for publication on 05.01.2017.

* Study conducted at Hospital Regional da Asa Norte - Brasília (DF), Brazil. Financial support: none.

Conflict of interest: none.

1 Advanced Surgery Outpatient Clinic of the Department of Dermatology at Hospital Regional da Asa Norte (HRAN), da Secretaria de Estado de Saúde do Distrito Federal (SES-DF) - Brasília (DF), Brazil.

2 Professional Masters in Health Sciences of the Escola Superior de Ciências da Saúde, Fundação de Ensino e Pesquisa em Ciências da Saúde, Secretaria de Estado de Saúde do Distrito Federal (ESCS-Fepecs-SES/DF) - Brasília (DF), Brazil.

(C2017 by Anais Brasileiros de Dermatologia 
TABLE 1: Epidemiologic profile of elderly with non-melanoma skin cancer at the public hospital tertiary center in Distrito Federal

\section{(absolute numbers and percentages)}

\begin{tabular}{|c|c|c|}
\hline Variables & $\mathbf{n}$ & $\%$ \\
\hline \multicolumn{3}{|l|}{$\operatorname{sex}$} \\
\hline male & 42 & 42 \\
\hline female & 59 & 58 \\
\hline \multicolumn{3}{|l|}{ age } \\
\hline $60-69$ & 27 & 27 \\
\hline $70-79$ & 47 & 47 \\
\hline $80-89$ & 19 & 19 \\
\hline over 90 & 8 & 8 \\
\hline \multicolumn{3}{|l|}{ race/skin color } \\
\hline white & 80 & 79 \\
\hline black & 4 & 4 \\
\hline yellow & 0 & 0 \\
\hline brown & 17 & 17 \\
\hline indígena & 0 & 0 \\
\hline \multicolumn{3}{|l|}{ years of education } \\
\hline $0-5$ years & 84 & 83 \\
\hline more than 5 years & 17 & 17 \\
\hline \multicolumn{3}{|l|}{ income } \\
\hline up to 1 minimum wage & 52 & 51 \\
\hline $2-5$ minimum wages & 43 & 43 \\
\hline 5 or more minimum wages & 6 & 6 \\
\hline \multicolumn{3}{|l|}{ daily use of sunscreen } \\
\hline yes & 22 & 22 \\
\hline no & 79 & 78 \\
\hline \multicolumn{3}{|l|}{ rural activity at any given time in life } \\
\hline yes & 53 & 52 \\
\hline no & 48 & 48 \\
\hline basal cell carcinoma (BCC) & 80 & 79 \\
\hline squamous cell carcinoma (SCC) & 21 & 21 \\
\hline high risk $\mathbf{B C C}$ on histology (sclerodermiform, basosquamous, micronodular, infiltrative) & 8 & 10 \\
\hline low risk BCC on histology (nodular and superficial) & 72 & 90 \\
\hline in situ SCC & 17 & 81 \\
\hline well differentiated SCC & 2 & 9 \\
\hline moderately differentiated SCC & 1 & 5 \\
\hline poorly differentiated SCC & 1 & 5 \\
\hline
\end{tabular}

The elderly NMSC population seen at the dermatology tertiary center has the following features regarding sociodemographic and clinical factors: majority female, low income and low schooling, predominance of occupations with ultraviolet radiation exposure without daily sunscreen use. The highlighted comorbidities are hypertension and diabetes mellitus, that are also the chronic, non-transmissible diseases more prevalent in the country's elderly population (Figure 1).

In face of the facts observed, it is vital to propose photoprotection measures, with simple information that can be easily understood, so that the health care professionals tailor their instructions, being closer to the elderly's life.
Photoprotection as skin cancer prevention does not include only sunscreen use, which would be difficult for these people to acquire, but also behavioral measures during daytime such as using long sleeved clothes, long pants and wide brimmed hats, and seeking shaded areas. It is important to note that these measures must be incorporated into these individuals' daily lives, so that they can pass them on to their families. This way, children and young people will benefit as well, avoiding the cumulative effects of sun exposure.

Since these individuals have the same comorbidity profile of the Brazilian population studied in the national health research of 2013 and by Vigitel 2014, whenever these patients attend health 


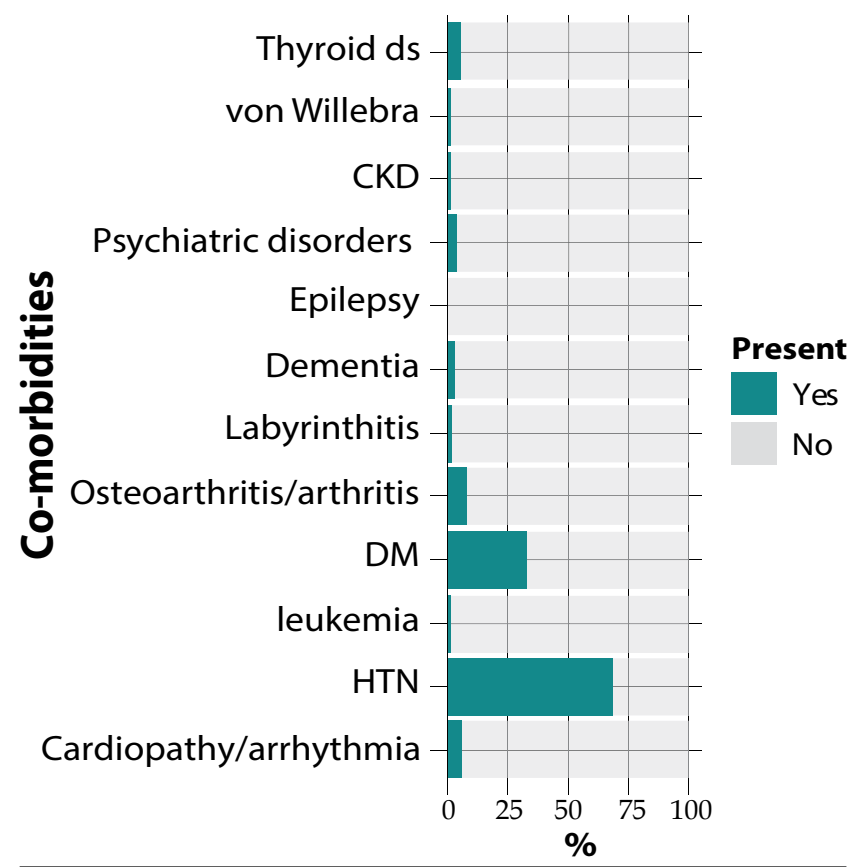

Subtitles: Thyroid ds: thyroid diseases; Von Willebra: von Willebrand disease; CKD: chronic kidney disease; Psychiatric disorders: psychiatric disorders; Epilepsy: epilepsy; Dementia: dementia ; Labyrinthitis: labyrinthitis; Osteoarthritis/arthritis: osteoarthritis/ arthritis; DM: diabetes mellitus ; Leukemia: leukemia ; HTN: hypertension; Cardiopathy/ arrhythmia: cardiopathy/arrhythmia

FIGURE 1: Most common chronic conditions in the elderly with non-melanoma skin cancer

\section{REFERENCES}

1. Nccn.org [Internet]. National Comprehensive Cancer Network. NCCN Clinical Practice Guidelines in Oncology (NCCN Guidelines) - Basal Cell Skin Cancer Version 1.2016 NCCN.org [cited 2016 Jan 22]. Available from: https://www.nccn. org/professionals/physician_gls/f_guidelines.asp

2. Inca.gov.br [Internet]. Instituto Nacional de Câncer José Alencar Gomes da Silva. Coordenação de Prevenção e Vigilância. Estimativa 2016 - Incidência de câncer no Brasil. Rio de Janeiro: Inca; 2015 [acesso 22 Jan 2016]. Disponível em: http:// www.inca.gov.br/estimativa/2016/estimativa-2016-v11.pdf

3. Ferreira FR, Nascimento LF, Rotta 0 . Fatores de risco para câncer de pele não melanoma em Taubaté, SP: um estudo caso-controle. Rev Assoc Med Bras (1992). 2011;57:424-30.

4. Pereira S, Curado MP, Ribeiro AMQ. Neoplasias múltiplas de pele em indivíduos com menos de 40 anos em Goiânia, Brasil. Rev Saúde Pública. 2015;49:64.

5. Biblioteca.ibge.gov.br [Internet]. Ministério do Planejamento, Orçamento e Gestão. Instituto Brasileiro de Geografia e Estatística - IBGE. Diretoria de Pesquisas Coordenação de Trabalho e Rendimento. Pesquisa nacional de saúde: 2013: acesso e utilização dos serviços de saúde, acidentes e violências : Brasil, grandes regiões e unidades da federação. Rio de Janeiro: IBGE; 2015 [acesso 23 Jan 2016]. Disponível em: http://biblioteca.ibge.gov.br/visualizacao/livros/ liv94074.pdf services they should be educated to maintain healthy life styles, potentially avoiding the terrible complications of chronic diseases such as diabetes and hypertension. ${ }^{5,6}$

Among the elderly people in this study, there was a predominance of BCCs and low risk SCCs with regards to local recurrence or metastasis. This is an important finding, for it reinforces the perception that health education measures that encourage self-skin checks and seeking medical assistance as early as possible are effective in increasing the cure rates for this condition and dramatically decreasing morbidity caused by mutilating surgeries that can happen with advanced stage disease.
6.

Brasil. Ministério da Saúde. Agência Nacional de Saúde Suplementar. Vigitel Brasil 2015 Saúde Suplementar : vigilância de fatores de risco e proteção para doenças crônicas por inquérito telefônico. Brasília: Ministério da Saúde; 2015. [acesso 23 Jan 2016]. Disponível em: http://www.ans.gov.br/images/stories/Materiais_para_ pesquisa/Materiais_por_assunto/2015_vigitel.pdf

\author{
MAILING ADDRESS: \\ Thiara Cristina Rocha Lenzi \\ SMHN, Quadra 1- Asa Norte \\ 70710-100 Brasília, DF \\ Brazil \\ E-mail:thiaramed@hotmail.com
}

How to cite this article: Lenzi TCR, Reis CMS, Novaes MRCG. Epidemiological profile of elderly patients with non-melanoma skin cancer seen at the dermatology outpatient clinic of a public hospital. An Bras Dermatol. 2017;92(6): 882-4. 